\title{
MITOGENIC PROPERTIES OF LECTIN FROM MUCUNA SLOANEI SEED EXTRACTS
}

\author{
S. P. MALU, G. O. OBOCHI, N. O. ALOBI, E. N. TAWO AND C. A. EDEM
}

(Received 10, July 2008; Revision Accepted 6, November 2008)

\begin{abstract}
Mitogenic properties of lectin from mucuna sloanei seed extracts were studied. The seeds of mucuna sloanie were shelled and ground using an electric grinder. The powder meal was then defatted with petroleum ether, and adjusted to $10 \%(\mathrm{w} / \mathrm{v})$ in potassium inorganic phosphates k-pi $(\mathrm{A})$ buffer $(\mathrm{pH} 7.5)$. The suspension was then filtered and clarified by centrifugation. The supernatant (crude extract) was then acidified and centrifuged at $4000 \times \mathrm{g}$ for 30 minutes. The supernatant generated was recovered. The materials were then extensively dialyzed, first against water and then against k-pi (A) buffer. Aliquots of the final dialysate were serially diluted (2-fold steps) in k-pi (A) buffer and used for haemagglutination assay and immunological parameters (i.e. percentages lymphocytes eosinophils, monocytes, basophiles, and neutrophils). The results showed that the isolated lectin from mucona sloanei seeds extracts agglutinated human $\mathrm{ABO}$, goat and chicken red blood cells, but did not agglutinate those of cow. It was also observed that the physicochemical properties of the lectin did not affect agglutination by variation of the $\mathrm{pH}$ of the medium or affected by temperature. The results of the immunological parameters showed that there were significant $(p<0.05)$ increases in the values of the immunological parameters relative to those seen in the controls. This study, suggest that the isolated lectin from mucona sloanei seeds possesses mitogenic properties, and may be useful in the diagnosis and treatment of certain diseases such as blood typing disorders and obesity.
\end{abstract}

KEYWORDS: Lectin, Mucuna Sloanei, agglutination, erythrocytes

\section{INTRODUCTION}

Lectins are glycoproteins found in a wide range of plants and animals and microorganisms They interact with specific carbohydrate residues (Cornard and Rudiger, 1994; Ray and Chatterjee, 1995; Ebong, 1999). Lectin distributions in seeds differ among various plant families. Many lectins have been grouped into distinct families of homogenous proteins with common structural properties (Ferrai et al., 1981; Eyo et al., 1985; Goldstein and Poretz, 1986; Shangary et al., 1995) and of these; the members of the Leguminosae have been most extensively studied (Eneobong and Carnoval, 1992; Shangary et al., 1995). The appearance of lectins in the seeds of most legumes occurs during the last stages of maturation of the seeds prior to their rehydration (Achinewhu, 1982, 1984; Afolabi et al, 1985; Aletor, 1985; Eyo et al., 1985). Most lectins are localized in the cotyledons (Eyo et al, 1985), and have specificity for a-mannose and high mannose structures (Sharon and Lis, 1972; Puztai et al., 1979; Wongkham et al., 1995; Zenteno et al., 1995; Shangary et al., 1995).

Mucuna sloanei (Efik-lbabat, Yakurr-Mpokpo, Igbo-Ukpo) is a leguminous plant that belongs to the Leguminosae. Its leaves are usually alternatively trifoliate, and its flowers have superior ovaries containing mostly 3-4 seed-bearing pods (i.e., one for each pollinated flower in the cluster (Figure 1-2) (SeaBean Guide, 2007). The fruit pods split along the dorsal sutures when mature to reveal the seeds; the seed coat is white-cream when immature, but beige with black banding when mature - this appearance leads to its receiving the moniker as The Hamburger Bean (Figure 3-4).

Mucuna Sloanei seeds contain high protein and crude fat contents(Ray and Chatterjee,1995).this may elevate their potential as a good source of meal, as well as its use as a preservative, flavoring agent, and thickener. Most of these latter effects arise from the high water binding capacity attributable to the formation of hydrogen bonds between water and polar residues on the protein molecules (Afolabi et al, 1985; Eyo et al., 1985; Goldstein and Poretz, 1986; Agbori, 1995). The seeds also contain a rich source of carbohydrates, among its total sugar composition; the seeds are high in glucose, fructose, mannose, and arabinose. The seeds have also been shown to bear high levels of potassium and calcium, but low levels of sodium (Wongkham et al, 1995). They can be used as an important supplement in low sodium diets prescribed for obese patients.

S. P. Malu, Department of Chemistry/ Biochemistry, Cross River University of Technology, Calabar, Cross River State- Nigeria.

G. O. Obochi, Department of Chemistry/ Biochemistry, Cross River University of Technology, Calabar, Cross River StateNigeria.

N. O. Alobi, Department of Chemistry/ Biochemistry, Cross River University of Technology, Calabar, Cross River State- Nigeria.

E. N. Tawo, Department of Chemistry/ Biochemistry, Cross River University of Technology, Calabar, Cross River State- Nigeria.

C. A. Edem, Department of Pure and Applied Chemistry, University of Calabar, Cross River State-Nigeria 


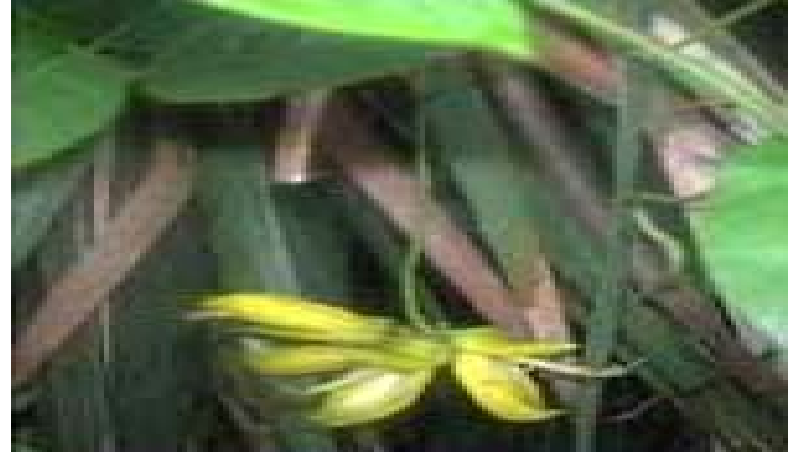

Fig.1:mucona sloanei plant

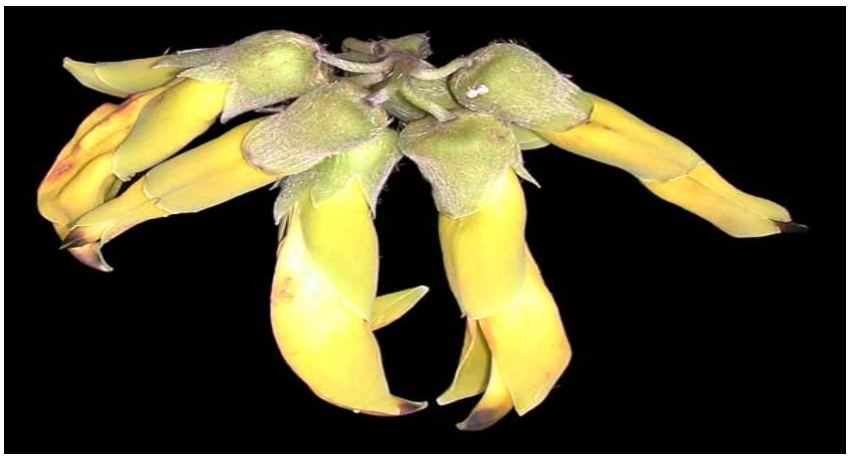

Fig.2: mucona sloanei flower

Lectins are useful reagents for the detection of the type and number of glycoproteins present on cell membranes. Thus, lectins are commonly used to test the role of carbohydrate-containing substances in many membrane-related events, including blood typing (Ray and Chatterjee, 1995; Zenteno et al., 1995; Shangary et al., 1995; Wongkham et al., 1995). Lectins recognize and bind specific sugars, including complex carbohydrate-containing materials found in polysaccharides and glycoproteins. Another well known property of lectins is their ability to stimulate lymphocytes (Shangary et al, 1995; Zenteno et al, 1995), leading to among other cellular events, their proliferation. Along these latter lines of thought, lectins also are useful in the examination of processes involved in converting resting cells into actively growing ones, i.e.,gene expression during the cell cycle (Stojavonic et al., 1994; Zenteno et al., 1995). These mitogenic properties of some lectins could indicate that they might have a natural role in the control of cell division. This study, therefore, focused on the assessment of the mitogenicity of the lectin from Mucuna sloanei as a cell receptor signal inducer, in part, by analyzing its agglutinating ability in blood cells from various animal types, including humans; and assessment of its immune parameters. (I.e. percentages lymphocytes, basophiles, monocytes and neutrophils.)

\section{MATERIALS AND METHODS}

\section{Collection and Preparation of Lectin from Mucuna Sloanei Seeds}

The seeds of mucuna sloanei (figure 4) were purchased at the Watt Market (Calabar, Nigeria). The

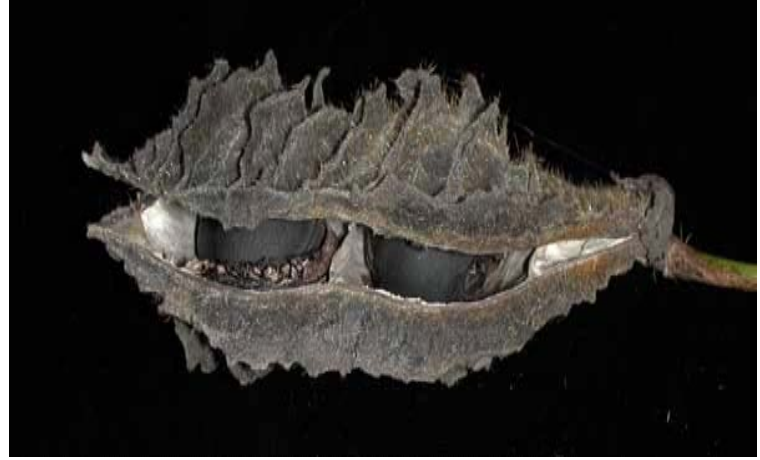

Fig.3: mucona sloanei pod

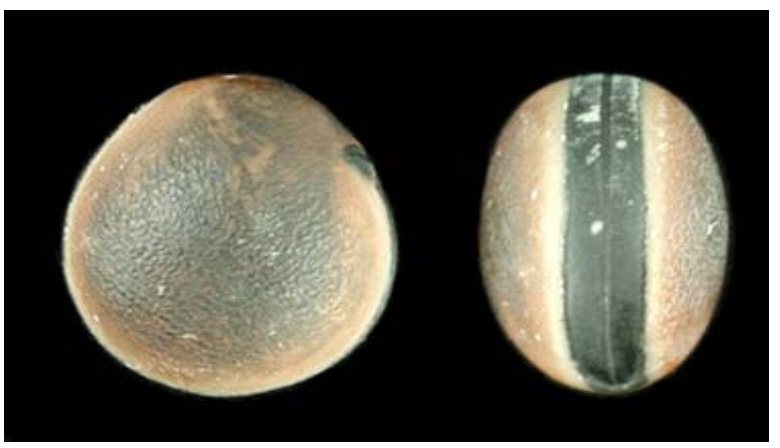

Fig.4:mucona sloanei seed

seeds were shelled and ground using an electric grinder. The powdered meal was then defatted with petroleum ether using a Soxhlet extractor at room temperature. Thereafter, $2.50 \mathrm{~g}$ of the defatted meal was adjusted to $10 \%(\mathrm{w} / \mathrm{v})$ in $\mathrm{K}-\mathrm{Pi}(\mathrm{A})$ buffer $(\mathrm{pH} 7.5)$ and stirred overnight. The suspension was then filtered through cheesecloth and clarified by centrifugation $(2000 \times$ g, 20 min). The $\mathrm{pH}$ of the supernatant (crude extract) was then brought to 4.3 by drop wise addition of $2 \mathrm{M}$ ammonium acetate $\left(\mathrm{NH}_{4} \mathrm{OAc}, \mathrm{pH}\right.$ 9.5), under constant stirring. To remove a precipitate that was formed, the mixture was stirred for $15 \mathrm{~min}$ at room temperature and then centrifuged $(4000 \mathrm{x} \mathrm{g})$ for $30 \mathrm{~min}$. The supernatant generated was recovered and its $\mathrm{pH}$ adjusted to 6.4 by addition of $2 \mathrm{M} \mathrm{NH}_{4} \mathrm{OAc}(\mathrm{pH}$ 9.5). The materials were then extensively dialyzed, first against water and then against $\mathrm{K}-\mathrm{Pi}(\mathrm{A})$ buffer ( $\mathrm{pH}$ 7.5), using $4 \mathrm{m \mu}$ pore size for $2 \mathrm{hrs}$. The concentration of the final dialysate was $20 \mathrm{mg} / \mathrm{ml}$ (i.e. $10 \mathrm{~g}$ lectin extract in $500 \mathrm{ml}$ distilled water or $\mathrm{k}-\mathrm{pi}(\mathrm{A})$ buffer. Aliquots of the final dialysate were serially diluted (2-fold steps) in k-pi (A) buffer and used for haemagglutination assay and immunological parameters assay. (I.e. percentages lymphocytes, eosinophils, basophiles, monocytes and neutrophils.) In the immune parameters assay,group 1( control )was whole blood only while group 2 contained whole blood + lectin.

\section{Haemagglutination Assay}

Haemagglutinating activity was determined with modifications of the method of Stojanvic et al. (1994). Human red blood cells (groups $A B O$ ) were obtained from healthy donors at the university teaching hospital in Calabar. Goat, cow, and chicken blood were procured 
from a local slaughterhouse in Bogobiri, (Calabar, Nigeria).for use in the study. The blood samples were collected into EDTA sterilized test tubes, and centrifuged at $2000 \times \mathrm{g}$ for $10 \mathrm{~min}$. the plasma + suspended red blood cells (whole blood )was used for haemagglutination assay. A stock solution $(20 \mathrm{mg} / \mathrm{ml})$ of the lectin solution was serially diluted (2-fold steps) in $\mathrm{K}-\mathrm{Pi}(\mathrm{A})$ buffer ( $\mathrm{pH} 7.5)$ and aliquots placed in test tubes. A suspension of the test erythrocytes (i.e., $15 \mathrm{ml}$ of $4 \%$ suspension of the test erythrocytes) was then added and the tube contents gently mixed by inversion. Haemagglutination titre was then determined (using simple observation of agglutina-tion at tube bottom) after $1 \mathrm{hr}$ incubation at room temperature. One unit of agglutination was defined as the lowest concentration of lectin that caused a positive agglutination under the experimental conditions used.

\section{Physicochemical Modification Assays}

The potential for the activities of the lectin to be modified by physicochemical changes were also determined with modifications of the method of Stojanovic et al (1994).to test the effect of varying $\mathrm{pH}$, a solution $(20 \mathrm{mg} / \mathrm{ml})$ of the lectin in k-pi(A)buffer (k-pH7.5) was exposed at $\mathrm{pH} 3.0$, $4.0,5.0,6.0,7.0,8.0,9.0$ or $\mathrm{pH} 10.0$ for $30 \mathrm{~min}$, and their haemagglutination then assayed. To test the effects of variations in temperature, a solution (20 $\mathrm{mg} / \mathrm{ml}$ ) of the lectin in $\mathrm{K}-\mathrm{Pi}(\mathrm{A})$ buffer ( $\mathrm{pH} 7.5)$ was exposed at $45,55,65$, or $75^{\circ} \mathrm{C}$ for $30 \mathrm{~min}$, and their haemagglutination then assayed. Each sample was tested in triplicate under the specified physicochemical condition.

\section{White blood cell (WBC) Differential Assays.}

White blood cell (WBC) differential were estimated using the standard method described by Osim et al (2004).Briefly,a dry micropipette was used to suck in blood from the blood sample bottle .A small drop of blood was applied to one end of a slide, and quickly placed on the bench holding it in position. The end of the second slide was then placed in the drop and held there until the blood had spread across it .It was then drawn slowly over the whole length of the first slide being held at an angle of $45^{\circ} \mathrm{C}$. After the blood had spread, it was dried before staining with Feishman's stain. The film was washed off in a gentle stream of water,dried with filter paper,and examined under low and high power microscope (Olympus binocular microscope) and the different kinds of WBC .(i.e. percentages lymphocytes, eosinophils, basophiles, monocytes and neutrophils.) were counted. The differential count is the relative number of each type of white cell in the blood. Multiplying the percentage value of each type by the total WBC count provides the number of each of white cell.

\section{Statistical Analysis.}

Data collected were expressed as mean \pm standard deviation (SD), students't' test was used for the analysis. A $p<0.005$ was considered to be statistically significant.

\section{RESULTS}

Table 1 presents the results of the haemogglutinating activity of the isolated lectin from Mucuna sloanei. The results showed that the lectin agglutinated human $\mathrm{ABO}$ erythrocytes as well as those of goat and chicken, but not those of cow.

The physicochemical properties of the lectin were also investigated (Tables 2 and 3 ). The results show that agglutination of human erythrocytes was not markedly affected by variations of the $\mathrm{pH}$ of the reaction medium (i.e., ranged from $3.0-10.0$ ). Similarly, the lectin seemed to retain its activity through a wide range of temperatures (i.e., from $45-75^{\circ} \mathrm{C}$ ). Table 2 presents results of the white blood cell (WBC) differential of the isolated lectin from mucona sloanei seeds. The results showed that there were significant $(p<0.05)$ increases $31.36 \%$ neutrophiles, $57.0 \%$ lymphocytes, $52.25 \%$ monocytes, $11.31 \%$ eosinophils, and $49.59 \%$ basophils respectively, in values of the blood + lectin group relative to those seen in the control group.

Table 1: Haemagglutinating activity of Mucuna sloanei lectin

\begin{tabular}{|c|c|}
\hline Blood sample & Agglutination \\
\hline Human A & + \\
\hline Human B & + \\
\hline Human O & + \\
\hline Goat & + \\
\hline Cow & + \\
\hline Chicken & + \\
\hline$+=$ Agglutination & \\
\hline$-=$ No agglutination & \\
\hline
\end{tabular}


Table 2: Effect of $\mathrm{pH}$ variation on agglutination

\begin{tabular}{|c|c|}
\hline $\mathrm{pH}$ & Agglutination \\
\hline 3.0 & + \\
\hline 4.0 & + \\
\hline 5.0 & + \\
\hline 6.0 & + \\
\hline 7.0 & + \\
\hline 8.0 & + \\
\hline 9.0 & + \\
\hline 10.0 & + \\
\hline
\end{tabular}

Table 3. Effect of temperature variation on agglutination

\begin{tabular}{|c|c|}
\hline Temperature $\left({ }^{\circ} \mathrm{C}\right)$ & Agglutination \\
\hline $45^{\circ}$ & + \\
\hline $55^{\circ}$ & + \\
\hline $65^{\circ}$ & + \\
\hline $75^{\circ}$ & + \\
\hline$+=$ Agglutination & \\
\hline
\end{tabular}

Table 4.Differential white blood cells (WBC) for human blood sample.

\begin{tabular}{|l|l|l|l|l|l|}
\hline Group & Neutrophils (\%) & Lymphocytes(\%) & Monoctes (\%) & $\begin{array}{l}\text { Eosinophils } \\
(\%)\end{array}$ & Basophils(\%) \\
\hline $\begin{array}{l}\text { 1.Control } \\
\text { (Blood only) }\end{array}$ & 40.1 & 28.93 & 5.81 & 1.96 & 1.84 \\
\hline $\begin{array}{c}\text { 2.Blood } \\
+ \\
\text { Lectin }\end{array}$ & 58.87 & 67.26 & 12.17 & 2.21 & 3.65 \\
\hline
\end{tabular}

Values are expressed as mean, student's' test used for comparison at $p<0.05$.

\section{DISCUSSION}

Haemagglutinating activity is shown in Table 1. The crude extract as well as the dialysate showed agglutination. The lectin agglutinated human red blood cells of either type A, B, O, though A and O showed more agglutination. It also agglutinated the red blood cells of goat and chicken but not those of cow. In the dialysate, there was a slight increase in haemagglutinating activity as compared to the crude extract. This is probably due to the removal of inhibitors initially present in the crude extract. Agglutination of human red blood cells (ABO) signified the presence of recognizable sugar residues, perhaps $\mathrm{N}$-acetyl-Dglucosamine or relative derivative of the erythrocyte membranes by the lectin (Ray and Chatterjee, 1995; Zenteno et al., 1995; Shangary et al., 1995). It also signified that the isolated lectin from mucuna sloanei seeds is a human red blood non-specific lectin (Stojanovic et al., 1994; Ray and Chatterjee, 1995; Zenteno et al., 1995; Wongkham et al., 1995).

The increase in neutrophils values in the whole blood + lectin treated group could be attributed to increased differentiation, growth and maturation of epithelial cells as well as activation of bone marrows ( Lampen,2000). The observed increase in lymphocytes values in the whole blood + lectin group could be attributed to increased proliferation of lymphocytes owing to stimulus effect of lectin in the blood, which had lead to rapid growth and cell division of the cells, which activated the immune response. In this study, the isolated lectin appeared to have induced formation of patch and caps on lymphocytes or lymphoids cells by binding specifically with carbohydrate receptor, i.e., by 
binding small lymphocytes and induced formation of caps and patch, which also induced cell division and differentiation of the small lymphocytes into larger, actively metabolizing cells( blast cells), rich in endoplasmic reticulum and ribosome, thus, acting on $\mathrm{T}$ and $B$ cells of the lymphoid cells, resulting in proliferation of lymphocytes and formation of antibodies. These observations might suggest that patching and capping may reflect important signals for antibody formation by specific cells in response to specific antigen. It also seems that the rate of glucose utilization by the lymphocytes increases markedly when the immune response is activated, and could result in the formation of antibodies in lymphoid cells. Lymphocyte proliferation is a common parameter which has been measured in several studies investigating the immunomodulatory effects (Gossage, 2000).

The increase in percentage monocytes could be attributed to the inhibition of oxidation of cellular lipids by lectin in the blood. Oxidation of lipids contributes to ageing, decline in immune system (due to superoxide ion $\left(\mathrm{O}_{2}^{-}\right)$toxicity which oxidizes thiol groups in proteins,alters nucleic acids and polysaccharides) Causes cancer, and degenerative diseases of the heart and nervous system (Gossage,2000).Also,an increased basophils in the blood + lectin group could be attributed to inhibition effect of lectin in the blood (as antioxidant) on initiation and propagation of free radical actions. Free radicals are generated as by-products of oxidative metabolism in the body or derived from exogenous sources, and are known to attack and destroys body proteins, polyunsaturated fats and DNA( Singh and Lippman,1998). Thus, the study suggests that the presence of lectin in the blood could protect plasma membrane from free radical induced oxidative damage.

Cell membrane is an assemblage of lipids and proteins. Protein molecules lie on the surfaces of the lipid bilayer or are embedded in it. This membrane architecture forms the framework for cell agglutination, crosslinking of cells by lectins that bind to specific receptors, sugar units of oligosaccharide chains protruding from the cell surface (Stojanovic et al., 1994; Ray and Chatterjee, 1995; Zenteno et al., 1995; Shangary et al., 1995). This clustering of the receptors indicates a change in the fluidity of the membrane, which allows for the pulling together of the receptor and their diffusion through the lipid bilayer of the membrane. The increased fluidity, characteristic of malignant cells could account, in part, for their decreased ability to migrate through the body from their tissues of origin. This could suggest that agglutination of lectin depends on relatively distribution of sugar receptors on the surface of cells where receptors are dispersed in normal cells and clustered in cells that have undergone malignant transformation or proteolysis. Thus, lectins may provide a useful tool for the study of chemical architecture of normal or transformed cell surfaces, for isolation of glycoconjugates and for use in other areas of biomedical sciences such as blood typing.

Conclusively, the study has shown that the isolated lectin from mucuna sloanei seeds extracts has been found to possess the mitogenic properties within a concentration range by agglutination and immunological parameters. This may suggests that this lectin possesses some therapeutic potential and could be used for mitogenic stimulation of normal human peripheral blood lymphocytes. This may also be useful in the diagnosis and treatment of certain diseases such as blood typing disorders and obesity.

\section{REFERENCES}

Achinewhu, S. C., 1982. Composition and food potential of African Oil bean seed pentaclethra macrophyllia and Velvet bean mucuna urens. J. Food Sci. Nutr. 47:1736-1742.

Achinewhu, S. C., 1984. Amino acid composition and nutritive value of proteins in velvet beans, mucuna urens. Plant Food Hum. Nutr. 34:181184.

Afolabi, O. A, Oshuntogun, B. A. Adewusi.,S. R. Fapojuwo, O. O, Ayorinde, F. O.Grissom, F. E. and Oke, O. L., 1985. Preliminary nutritional and chemical evaluation of raw seeds of Mucuna solaonei:An underutilized food source. J. Agr. Food Chem. 33:122-124.

Agbori, R., 1995. Extraction and estimation of lectin from mucuna sloanei seed. A PhD Thesis, Department of Microbiology,the Polytechnic Calabar.pp.1-3

Aletor, V. A., 1987. Nutritional studies with rats fed with lima beans (phaseolus innatus) haemaglutinin extract. J. Anim. Physiol. Anim. Nutr. 57:32-41.

Ray, S. and Chatterjee, B. P., 1995. A lectin from saraca indica seeds integument recognizes complex carbohydrates. Phytochemistry 40: 643 - 649.

Cornard, F., and Rudiger, H., 1994. The lectin from pleurotus ostreatus: Purification, characterization and interaction with a phosphatase. Phytochemisty36:277-282

Ebong, P. E. (Ed.), 1999. Lectins. In: Principles and Applications of Biochemical Techniques, First Edition. The University of Calabar Press: Calabar, Nigeria, pp.59.

Eneobong, H. N., and Carnoval, E., 1992. A comparison of the proximate mineral and amino acid composition of some known and lesser known legumes in Nigeria. J. Food Chem. 43:169-175.

Eyo, E. S, Mohammed, H., and Abel, H. J., 1985. The composition of carbohydrates and proteins in the seeds of Irvingia gabonensis, cucumeropsis manni and mucuna sloanei. Plant Res. Dev. 13:109-113.

Ferrari, T. E., Bruns, D., and Wallace, D. H., 1981. Isolation of a plant glycoprotein involved with control of intercellular recognition. Plant Physiol. 67:270-277. 
Goldstein, I. J., and Poretz, R. D., 1986. Lectins: Properties, functions and applications in biology and medicine. In: Properties and Application of Glycoprotein (Liener, I. E., Sharon, N., and Goldstein, J., Eds). Pp. 33 - 34.

Gossage, E., 2000. Effect of B-Carotene Supplementation and lactation on carotenoid metabolism and mitogenic T-lymphocyte Proliferation.A M. J. Clin. Nutri. 71: 950 - 955.

Lampen, A., 2000. Ultraviolet light-induced reductions in plasma carotenoid levels. A M. J. Clin. Nutri. 47: 879-882.

Osim, E. E., Akpogomeh, B. A., Ibu, J. O. ,Eno, A. E.,

2004. Blood Analysis in Manual of Experimental Physiology. $3^{\text {rd }}$ Edition. Osim, E. E (Ed.). University of Calabar Press, Calabar, Nigeria. pp. 60-81.

Pusztai, A., Clarke, E. M., and King, T., 1979. The nutritional toxicity of phaseolus vulgaris lectins. Proc. Nutr. Soc. 38:115-120.

Shangary, S., Singh, J., Kamboj, S. S., Kmboj, K. K., and Sandhu, S. R., 1995. Purification and properties of four monocot lectins from the family Araceae. Phytochemisty 40: 449 - 455.

Sharon, N., and Lis, H., 1972. Lectin: Cell-agglutinate and sugar-specific proteins. Science 177: 949 960.

Singh, D. K and Lippman, S. M., 1998. Cancer Chemoprevention:Retiniods,Caroteniods and other classic antioxidants.Oncology 2: 1643 1648.

Stojanovic, D., Fernandez, M., Casale, I., Trujillo, D., and Castes, M., 1994. Characterization and mitogencity of a lectin from Erythrina velutina seeds. Phytochemistry 37:1069-1074.

Wongkham, S., Wongkham, C., Boonsiri, P., Simasathiansophon S, Trisonthi, C., and Atisook, K., 1995. Isolectin from seeds of Artocarpus lakoocha. Phytochemistry 40: 1331 - 1334.

Zenteno, R., Chavez, R., Portugal, D., Paez, A., Lascurian, R., and Zenteno, E., 1995. Purification of a $\mathrm{N}$-acetyl-D-glucosamine specific lectin from the orchid laelia. autumnalis Phytochemistry 40: 651 $-655$. 